Article

\title{
Farmers' Perceptions of Climate Change and Agricultural Adaptation in Burkina Faso
}

\author{
Jorge Alvar-Beltrán ${ }^{1, *(1)}$, Abdalla Dao ${ }^{2}(0)$, Anna Dalla Marta ${ }^{1}\left(\mathbb{D}\right.$, Ana Heureux ${ }^{3}$, Jacob Sanou ${ }^{2}$ \\ and Simone Orlandini ${ }^{1}$ (D) \\ 1 Department of Agriculture, Food, Environment and Forestry (DAGRI), University of Florence, \\ 50144 Firenze FI, Italy; anna.dallamarta@unifi.it (A.D.M.); simone.orlandini@unifi.it (S.O.) \\ 2 Institut de l'Environnement et Recherches Agricoles (INERA), Bobo Dioulasso BP910, Burkina Faso; \\ adao@wacci.ug.edu.gh (A.D.); jsanou24@yahoo.fr (J.S.) \\ 3 Food and Agriculture Organization of the United Nations (FAO), 00153 Roma RM, Italy; \\ Ana.Heureux@fao.org \\ * Correspondence: jorge.alvar@unifi.it
}

Received: 26 June 2020; Accepted: 31 July 2020; Published: 5 August 2020

check for updates

\begin{abstract}
The Sahel region is considered a hotspot for climate change hazards and vulnerability of weather reliant sectors, including agriculture. Farmers in Burkina Faso have a long history of adapting their farming activities to frequent changes in climate. Using 150 in-person surveys, this study assesses farmers' perceptions of climate change based on multiple climate variables, and reviews adaptation practices, including soil and water conservation strategies, in the Soudanian, Soudano-Sahelian, and Sahelian agroclimatic zones of Burkina Faso. In general, farmers are aware of changing climatic conditions, including increased temperatures, greater rainfall variability, heavier precipitation events, delayed onset, and premature offset of the rainy season. However, farmers perceive shifts in climate differently depending on their location and agroclimatic zone. As a result, different adaption strategies are implemented by farmers according to the climatic, societal, and economic context. Survey results show that in the Sahel, climate adaptation strategies rely on traditional knowledge and experimental approaches; whereas in the Soudanian zone, where weather conditions are more favorable for agriculture, adaptation practices are market oriented. These regional differences are important for targeting advisory services, planning processes, and decision-making to support the effective provision of weather and climate information services to the last mile.
\end{abstract}

Keywords: Sahel; climatic trends; extreme weather events; climate services; climate resilience

\section{Introduction}

The Sahel region and Western Africa observed a warming of $0.5-0.8^{\circ} \mathrm{C}$ over the period 1979 to 2010, with warmer day and nighttime temperatures. Warming in this region is more significant than the average over the rest of Africa [1-4]. In Burkina Faso, over the period of 1950 to 2013, a positive trend of the hottest day in the year and hot-day frequency across the country was observed [5]. Future temperature projections suggest a $1-2{ }^{\circ} \mathrm{C}, 2-4{ }^{\circ} \mathrm{C}$, and $5-7{ }^{\circ} \mathrm{C}$ increase under representative concentration pathway (RCP) 2.5, 4.5 and 8.5, respectively, from June to August by the end of the century [6].

Since the late 1960s, the region has experienced increasing inter-annual rainfall variability [7]. Despite the decrease in annual rainfall totals, some studies suggest a regreening of the Sahel in the last two decades, a likely result of consecutive years of rainfall recovery [8-11]. Other authors assert that dry-spells are now shorter but more frequent than the historical average, while some associate the shift in dry-spells (June-July) to the warming of the tropical-Atlantic Ocean [12,13]. Uncertainty remains for 
precipitation projections, with a range of possible precipitation scenarios (varying between $-30 \%$ and $+30 \%$ ) depending on the model and scenario applied over West Africa [14,15].

Development challenges faced by Sub-Saharan countries include unsustainable population growth, endemic poverty, lack of governance, poor educational and healthcare systems, impoverished infrastructures, and increasing conflict, as well as degraded environments. All these factors reflect the relatively low adaptive capacity and high vulnerability of livelihoods to weather-related hazards [16-18] (Table 1.).

Table 1. Some of the observed agricultural adaptation strategies in Western Sahel.

\begin{tabular}{lll}
\hline \multicolumn{1}{c}{ Practice } & \multicolumn{1}{c}{ Description } & Reference \\
\hline Livestock mobility & $\begin{array}{l}\text { Promotes the optimal utilization of spatially heterogenous } \\
\text { availability of forage and water resources }\end{array}$ & {$[19]$} \\
\hline Climate resilient crops & Quinoa (Chenopodium quinoa Willd.) promotion in the Sahel & {$[20]$} \\
\hline Vallerani systems & $\begin{array}{l}\text { Water harvesting catchments using a tractor for sowing shrubs } \\
\text { and trees }\end{array}$ & {$[21]$} \\
\hline Planting trenches & Soil-stabilization technique through tree cover restoration & [22] \\
\hline Contour ridges & Water micro-catchment technique using ridges spacing 1-2 m & [22] \\
\hline Sand-dune stabilization & $\begin{array}{l}\text { Combination of mechanical and biological measures (fences } \\
\text { and grass) }\end{array}$ & [22] \\
\hline Contour bunds & Water micro-catchment technique using stone bunds & [23] \\
\hline Mulching & Reduce the evaporation of remaining moisture from the soil & [24] \\
\hline Zaï-pit system & $\begin{array}{l}\text { Planting pits to rehabilitate barren land, improve infiltration } \\
\text { and nutrient availability for plants }\end{array}$ & [24] \\
\hline Vegetative strips & Vegetation establishment for soil erosion reduction & [25] \\
\hline Agroforestry & $\begin{array}{l}\text { Agricultural areas interspersed by self-generating and local } \\
\text { tree species }\end{array}$ & [26] \\
\hline
\end{tabular}

The application of the abovementioned practices (Table 1) provide evidence of adaptation among local populations [27]. In Burkina Faso, several studies have examined the typology of farmers' adaptation, awareness of climate hazards, and past climatic trends [28-36].

While the aforementioned studies have outlined existing practices applied in the country, there is a lack of understanding of farmers' perceptions of climate and the available options for effective adaptation. Current literature does not provide a comprehensive assessment of farmers' perceptions of climate compared against climatic trends across the different agroclimatic zones and agrometeorological services as a way to build climate resilience. Therefore, there is a knowledge gap that hinders the effective adaptation of farmers to climate change. In the present study, farmers' awareness of climate change (for the past 10-20 years), adaptation measures, vulnerability, and provision of climate services are evaluated in order to inform a framework for climate change adaptation for farmers in Burkina Faso. Finally, the study analyzes meteorological data over a 45-year timeframe to examine observed climate trends compared to farmers' perceptions. This work builds upon previous studies by elucidating how farmers' perceptions mirror climatic trends and identifying gaps and needs for more effective adaptation at a farm level. Recommendations are provided to improve current agrometeorological decision-making by farmers and strengthen climate resilience amongst those most vulnerable to the future impacts of climate change. 


\section{Materials and Methods}

\subsection{Study Area and Farmer Surveys}

Structured farmer surveys, conducted between February and April 2018, were randomly distributed in hard-copy to 150 smallholder farmers (cropping systems) located in 17 provinces along Burkina Faso's different agroclimatic zones defined by annual rainfall: Sahelian (400-600 mm year ${ }^{-1}$; 38 surveys), Soudano-Sahelian (600-900 $\mathrm{mm}$ year $^{-1}$; 56 surveys) and Soudanian (more than $900 \mathrm{~mm}$ year $^{-1} ; 56$ surveys) (Figure 1). Each survey was composed of 17 questions and were divided as follows: (a) farmers' perceptions on hydro-climatic events (1-8), (b) climate change impacts and vulnerability (9-12), (c) agricultural adaptation and climate services (13-17). To investigate whether farmers had observed changes in temperature, precipitation, and wind patterns, the time frame used in this study was 10 to 20 years. Semantic barriers were overcome by translating the survey to local languages (Mooré, Dyula, and Fula), otherwise the survey was carried out in French.

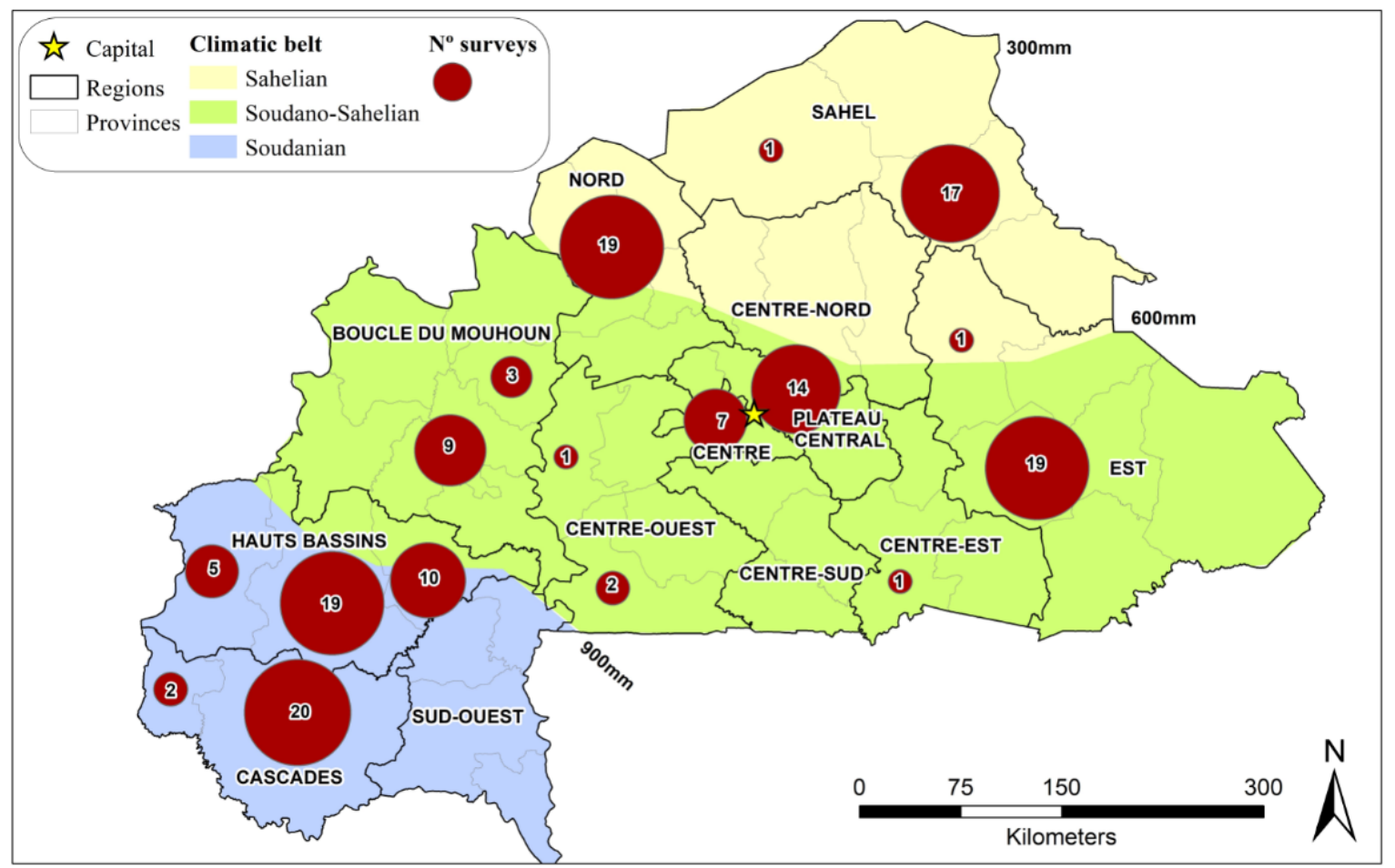

Figure 1. Spatial distribution of surveys along the different agroclimatic zones (Sahelian, Soudano-Sahelian, and Soudanian).

\subsection{Socio-Economic Characteristics and Farm Typology}

Women farmers in Burkina Faso have limited access to land and therefore the number of women surveyed was considerably lower (18\%) than that of men (Table 2). Of the farmers surveyed, $42 \% \mathrm{knew}$ how to read and write, while $62 \%$ were between 20 and 49 years old. The majority of the farmers (53\%) had fields sizing between 1 and 5 ha, and 10\% were recognized as having more than 20 ha. The crops grown in Burkina Faso vary according to the agroclimatic zone. The survey baseline responses showed that Soudanian farmers grow crops with higher water requirements and based their agricultural activities on a market-oriented economy (42\% maize, 13\% rice, and 9\% cotton), while Soudano-Sahelian farmers had a more diversified income (28\% maize, 16\% millet, 13\% black-eyed peas, 10\% vegetables and cotton, $9 \%$ both for sesame and sorghum). Sahelian farmers based their farming systems on low water requirements and subsistence agriculture (34\% millet, 29\% sorghum, 11\% both for vegetables and black-eyed peas). 
Table 2. Socio-economic characteristics of farmers surveyed and farm typology (as \% of respondents) across the different agroclimatic zones.

\begin{tabular}{|c|c|c|c|c|c|c|c|c|c|c|c|c|c|}
\hline \multirow{2}{*}{ Agroclimatic Zone } & \multicolumn{2}{|c|}{ Gender } & \multicolumn{2}{|c|}{ Literacy Rate } & \multicolumn{4}{|c|}{ Farmers Age (Years) } & \multicolumn{5}{|c|}{ Farm Size (ha) } \\
\hline & Male & Women & Yes & No & $20-29$ & $30-39$ & $40-49$ & $50+$ & $<1$ & $1-4$ & $5-9$ & 10-19 & $20+$ \\
\hline Soudanian & 86 & 14 & 61 & 39 & 10 & 30 & 28 & 32 & 14 & 38 & 14 & 20 & 14 \\
\hline Soudano-Sahelian & 68 & 32 & 35 & 65 & 12 & 35 & 29 & 24 & 28 & 50 & 10 & 2 & 10 \\
\hline Sahelian & 97 & 3 & 22 & 78 & 0 & 42 & 29 & 29 & 4 & 96 & 0 & 0 & 0 \\
\hline Total & 82 & 18 & 42 & 58 & 10 & 34 & 28 & 28 & 18 & 53 & 10 & 9 & 10 \\
\hline
\end{tabular}

Legend: the total number of surveys (156) were distributed as follows: Soudanian (56), Soudano-Sahelian (56), Sahelian (38).

\subsection{Climate Data}

Past daily precipitation $(\mathrm{mm})$ and minimum/maximum temperature (hereafter, Tmax and Tmin in ${ }^{\circ} \mathrm{C}$ ) data were retrieved from the National Oceanic and Atmospheric Administration (NOAA) [37] for the historical period 1973-2017 (45 years). Three synoptic automatic weather stations were selected for completeness over the time period (data coverage between $88 \%-95 \%$ ), and were used to analyze changing climatic trends across the different agroclimatic zones: Sahel (Dori; $14^{\circ} 01^{\prime} \mathrm{N} 0^{\circ} 01^{\prime} \mathrm{W}$; 280 m.a.s.l.), Soudano-Sahelian (Ouagadougou airport; $12^{\circ} 21^{\prime} \mathrm{N} 1^{\circ} 30^{\prime}$ W; 310 m.a.s.l.), and Soudanian (Bobo Dioulasso airport; $11^{\circ} 09^{\prime} 4^{\circ} 19^{\prime} \mathrm{W} ; 450$ m.a.s.l.). For the missing values, a rescaling of the neighbor series (pre-bias correction) was conducted using neighboring temporal data rather than neighboring spatial data (as the distance of closest weather stations and missing data was too large [38]. To reduce the error, the 45-year time series was divided in 10-year time periods (1973-1982, 1983-1992,1993-2002, 2003-2012, 2013-2017) to later calculate the arithmetic mean for a specific time period. This technique minimized the under/overestimation of the observations.

Trends in climate variables were examined by means of linear regression as well as by trends at a decadal temporal scale. The trends of climate extremes, maximum temperature above $40{ }^{\circ} \mathrm{C}$ (hereafter T40max), was calculated using daily data for the 1973-2017 period. The coefficient of variation (cv), expressed as a percentage, was used to estimate the variation on interannual precipitation Equation (1). Heavy rainfall events were defined as days with precipitation higher than $20 \mathrm{~mm} \mathrm{day}{ }^{-1}$. The shifts in onset and offset of the rainy season were evaluated on a 10-day basis; while the start and the end of the rainy season was determined once $5 \%$ and $95 \%$, respectively, of the total annual precipitation was attained [39]. Changes in dry-spell frequency ( 7 or more consecutive days with no precipitation during the rainy season) were evaluated accordingly to the length of the rainy season in each agroclimatic zone: Soudanian (1 May-1 October), Soudano-Sahelian (20 May-20 September), and Dori (1 June-1 September).

$$
\mathrm{CV}=\frac{\sigma}{\mu}
$$

where $\sigma$ and $\mu$ corresponded to the standard deviation and precipitation mean for the period of interest.

Furthermore, farmers appraisals from surveys were compared with empirical ground-based information from weather stations to evaluate the consistency between these two datasets. The emerging findings from the surveys was examined as the ratio between the number of answers and total number of respondents per agroclimatic zone, as a percentage. In addition, the analysis of variance (ANOVA) as well as the Tukey HSD post-hoc tests were used to determine which specific groups (possible answers) were significantly different $(p<0.05)$ from each other. The ANOVA and Tukey HSD test were conducted using the statistical software Minitab 19 (version 2.0). 


\section{Results}

\subsection{Past Climatic Trends}

The period 1973-2017 was the basis for the analysis of all climatic information (air temperature and precipitation) across the country's three agroclimatic zones. Annual maximum and minimum air temperatures increased in all three stations, but the rate of increase was greater for Tmin than for Tmax (Figures 2 and 3). The increasing trends in Tmax were more significant for the Soudanian and Soudano-Sahelian zone $\left(p<0.001 ; 0.29\right.$ and $0.27^{\circ} \mathrm{C}$ decade ${ }^{-1}$, respectively) than for the Sahelian zone $\left(p>0.05 ; 0.04{ }^{\circ} \mathrm{C}\right.$ decade $\left.{ }^{-1}\right)$. From 1973 to 2017 , Tmax increased by $1.26{ }^{\circ} \mathrm{C}$ in southern and central parts of the country and by $0.18^{\circ} \mathrm{C}$ in northern parts. The increase in Tmax (Table 3) was reflected in the number of hot days per year with temperatures exceeding $40{ }^{\circ} \mathrm{C}$ (T40max). Even though the Sahel region did not experience an increase in T40max during this period, T40max was recorded on average 100 days year ${ }^{-1}$. However, the greatest increase was observed in the capital, Ouagadougou (from 30 to 60 days year ${ }^{-1}$ ), and in the second largest city, Bobo Dioulasso (from 1 to 6 days year $^{-1}$ ), when comparing the 1973-1982 with the 2013-2017 period. T40max increase was exacerbated by the coupled effect of urban expansion and changes in vegetation cover. In addition, Tmin increase was significant at all three stations $(p<0.001)$, particularly in the Sahel $\left(0.41^{\circ} \mathrm{C}\right.$ decade $\left.{ }^{-1}\right)$ and, to a lesser extent, in the Soudanian and Soudano-Sahelian zone $\left(0.22\right.$ and $0.17^{\circ} \mathrm{C}$ decade ${ }^{-1}$, respectively).

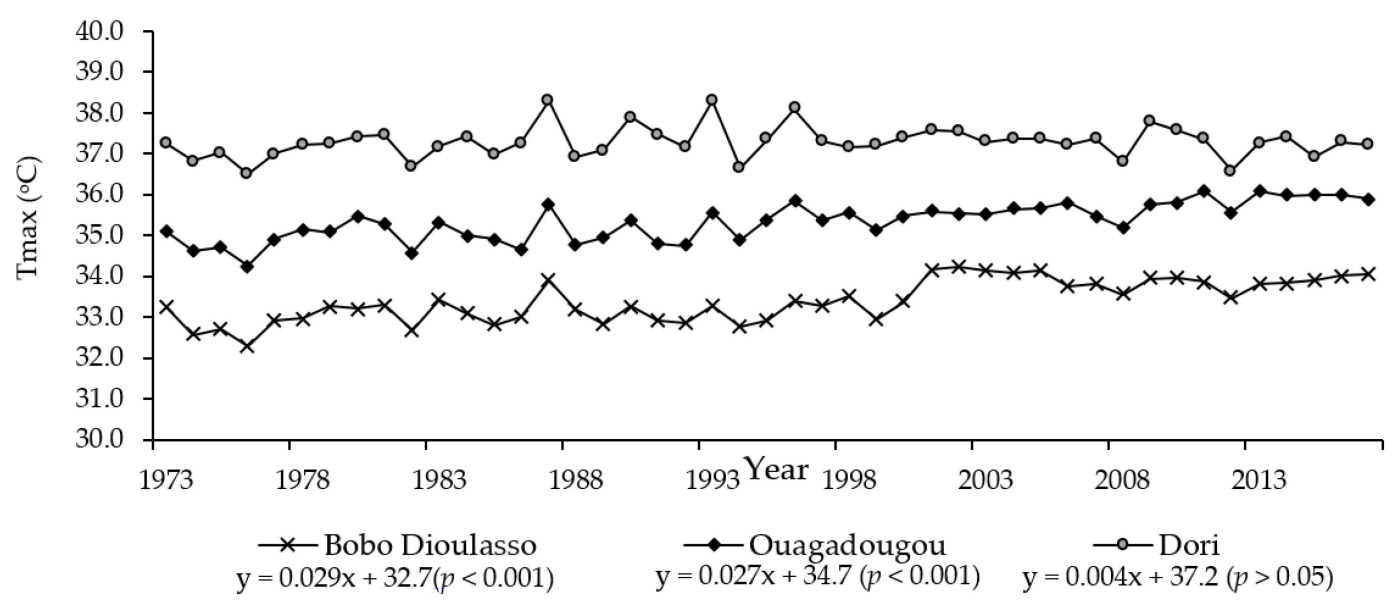

Figure 2. Mean annual maximum temperature (Tmax), lineal regression, and statistical significance along the different agroclimatic zones (Soudanian, Soudano-Sahelian, and Sahelian) for the period 1973-2017.

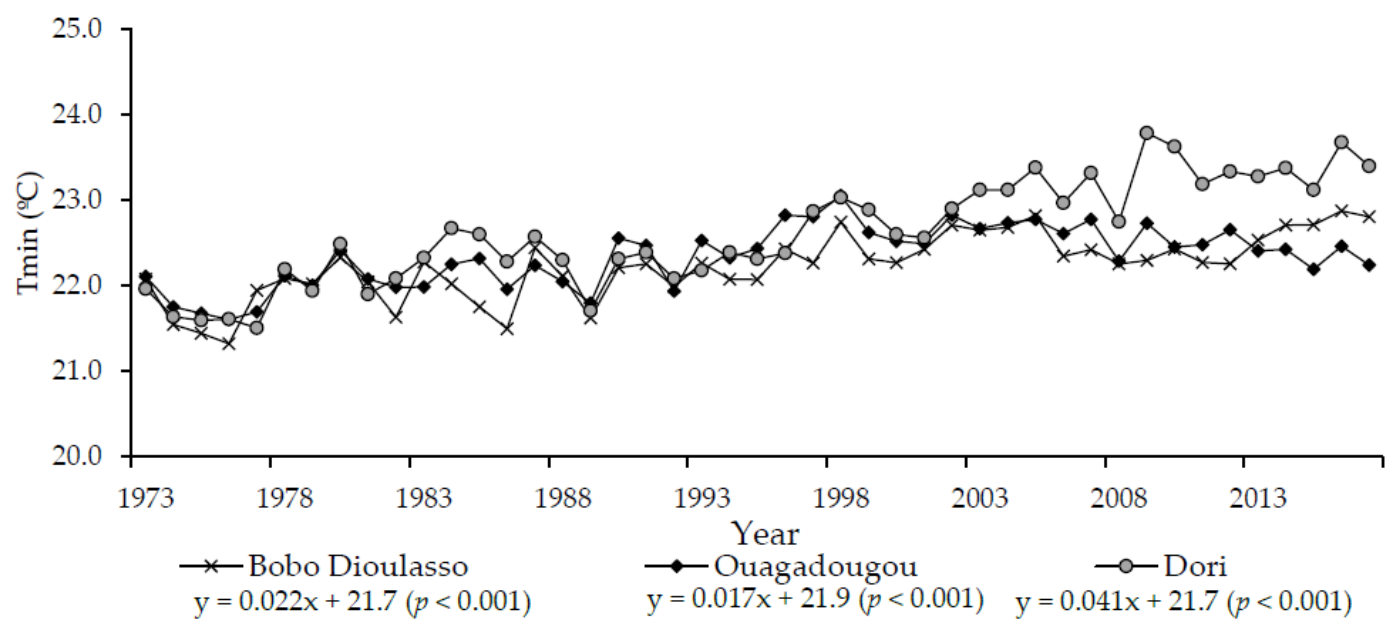

Figure 3. Mean annual minimum temperature (Tmin), lineal regression, and statistical significance along the different agroclimatic zones (Soudanian, Soudano-Sahelian, and Sahelian) for the period 1973-2017. 
Table 3. Changes in the number of days per year with temperatures above $40{ }^{\circ} \mathrm{C}$ along the different agroclimatic zones (Soudanian, Soudano-Sahelian, and Sahelian) for the period 1973-2017.

\begin{tabular}{ccccccc}
\hline & \multicolumn{2}{c}{ Soudanian } & \multicolumn{2}{c}{ Soudano-Sahelian } & \multicolumn{2}{c}{ Sahelian } \\
\hline Period & Number & Difference (\%) & Number & Difference (\%) & Number & Difference (\%) \\
\hline $1973-1982$ & 1 & - & 30 & - & 99 & - \\
$1983-1992$ & 2 & +100.0 & 29 & -3.3 & 98 & -1.0 \\
$1993-2002$ & 2 & +100.0 & 38 & +26.7 & 102 & +3.0 \\
$2003-2012$ & 6 & +500.0 & 44 & +46.7 & 94 & -5.1 \\
$2013-2017$ & 6 & +500.0 & 60 & +100.0 & 98 & -1.0 \\
\hline
\end{tabular}

All three sites showed decreasing trends in annual precipitation (Figure 4), which were significantly different in the Soudano-Sahelian and Sahelian zone ( $p<0.001$ and $p<0.05$, respectively), but not in the Soudanian zone $(p>0.05)$. The decreasing trends in yearly precipitation ranged from $55.8 \mathrm{~mm}$ decade $^{-1}$ (Ouagadougou) to $3.4 \mathrm{~mm}$ decade $^{-1}$ (Bobo Dioulasso). However, decreasing precipitation trends were not consistent throughout the study period (1973-2017), with a precipitation recovery over most recent years (2013-2017) when compared to the previous study period (2003-2012). The sharpest precipitation decrease was noted in the 80s, 90s and early 00s in the Sahel and Soudano-Sahelian region, whereas precipitation remained constant in the Soudanian zone. In addition, the coefficient of variation (cv) showed a significant increase in interannual rainfall variability throughout the 1972-2017 period (Table 4). For instance, the cv in 1972-1983 was of 5.6, 9.2, and 12.0; while in 2003-2012, the cv was of 10.0, 18.6, 20.2 in Bobo Dioulasso, Ouagadougou, and Dori, respectively. These values suggest that rainfall variability was largest in northern parts of the country (Sahel zone) when compared to the southernmost parts (Soudanian zone). The dry-spell frequency (more than seven days without any precipitation during the rainy season) increased in all agroclimatic zones throughout the study period: Soudanian (from 2.9 to 4.5 dry spells year ${ }^{-1}$ ), Soudano-Sahelian (from 2.4 to 5.2 dry spells year ${ }^{-1}$ ), and Sahelian (from 2.8 to 4.0 dry spells year ${ }^{-1}$ ) (Table 5). A similar pattern was observed for rainfall intensity (prec. $>20 \mathrm{~mm} \mathrm{day}^{-1}$ ) with an increase over time (e.g., from 5.4 to 7.0 days $^{-1}$ year $^{-1}$ when comparing 1973-1982 with 2013-2017 in the Sahelian zone) (Table 5).

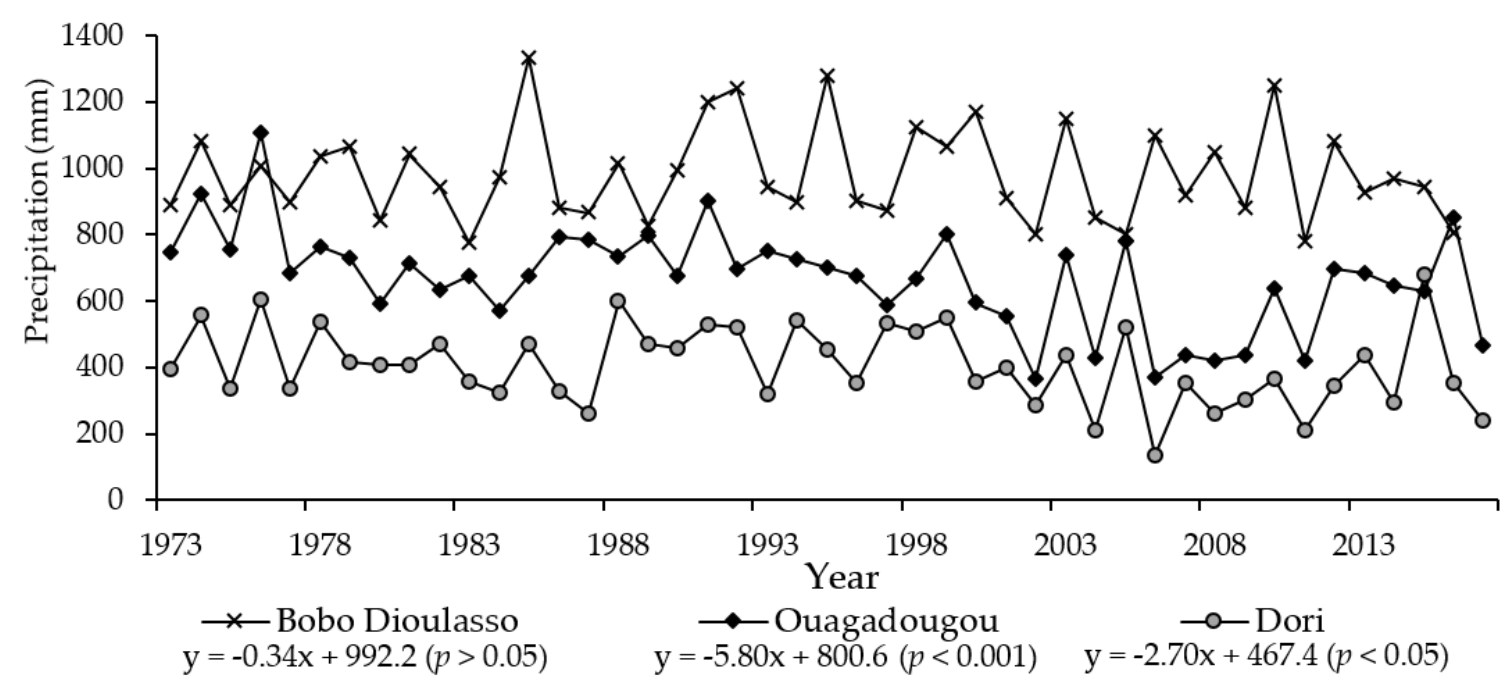

Figure 4. Total annual precipitation ( $\mathrm{mm}$ ), lineal regression, and statistical significance along the different agroclimatic zones (Soudanian, Soudano-Sahelian, and Sahelian) for the period 1973-2017. 
Table 4. Changes in annual precipitation $(\mu)$ and interannual rainfall variability (cv) along the different agroclimatic zones (Soudanian, Soudano-Sahelian, and Sahelian) for the period 1973-2017.

\begin{tabular}{ccccccc}
\hline & \multicolumn{2}{c}{ Soudanian } & \multicolumn{2}{c}{ Soudano-Sahelian } & \multicolumn{2}{c}{ Sahelian } \\
\hline Period & $\boldsymbol{\mu}(\mathbf{m m})$ & $\mathbf{c v}(\mathbf{\%})$ & $\boldsymbol{\mu}(\mathbf{m m})$ & $\mathbf{c v}(\mathbf{\%})$ & $\mu(\mathbf{m m})$ & $\mathbf{c v}(\mathbf{\%})$ \\
\hline $1973-1982$ & 970 & 5.6 & 765 & 9.2 & 447 & 12.0 \\
$1983-1992$ & 1010 & 10.4 & 731 & 6.9 & 432 & 15.0 \\
$1993-2002$ & 996 & 9.3 & 642 & 10.4 & 430 & 14.4 \\
$2003-2012$ & 986 & 10.0 & 537 & 18.6 & 314 & 20.2 \\
$2013-2017$ & 910 & 4.1 & 656 & 9.7 & 401 & 22.2 \\
\hline
\end{tabular}

Legend: average precipitation for Bobo Dioulasso (983 mm), Ouagadougou (667 mm), and Dori (405 $\mathrm{mm})$ for the period 1973-2017.

Table 5. Changes in dry-spell frequency (seven days or more without rain) and precipitation intensity $\left(>20 \mathrm{~mm} \mathrm{day}^{-1}\right.$ ) along the different agroclimatic zones (Soudanian, Soudano-Sahelian, and Sahelian) for the period 1973-2017.

\begin{tabular}{|c|c|c|c|c|c|c|}
\hline \multirow[b]{2}{*}{ Period } & \multicolumn{2}{|c|}{ Soudanian } & \multicolumn{2}{|c|}{ Soudano-Sahelian } & \multicolumn{2}{|c|}{ Sahelian } \\
\hline & Dry Spells (year ${ }^{-1}$ ) & Prec20 (mm) & Dry Spells (year ${ }^{-1}$ ) & $\operatorname{Prec} 20(\mathrm{~mm})$ & Dry Spells (year ${ }^{-1}$ ) & Prec20 (mm) \\
\hline 1973-1982 & 2.9 & 18.0 & 2.4 & 9.5 & 2.8 & 5.4 \\
\hline 1983-1992 & 2.9 & 15.1 & 2.4 & 10.7 & 2.9 & 5.9 \\
\hline 1993-2002 & 3.1 & 14.7 & 3.3 & 9.4 & 2.6 & 6.2 \\
\hline 2003-2012 & 4.3 & 13.8 & 3.6 & 9.6 & 4.0 & 5.1 \\
\hline 2013-2017 & 4.5 & 16.8 & 5.2 & 11.8 & 4.0 & 7.0 \\
\hline
\end{tabular}

The long time series showed a shortening of the rainy season in all agroclimatic zones: from 180 to 150 days in the Soudanian, from 140 to 100 days in the Soudano-Sahelian, and from 90 to 70 days in the Sahelian zone for the period 1973-2017 (Table 6). A delayed start of the rainy season was observed in all agroclimatic zones, from 20 April to 10 May in the Soudanian zone, from 1 May to 1 June in the Soudano-Sahelian zone, and from 20 May to 20 June in the Sahelian zone when comparing the 1973-1982 and 2003-2012 periods. In addition, the Soudanian zone experienced a notable advancing of the offset of the rainy season from 20 October to 20 September, respectively, when comparing the 1973-2002 and 2003-2012 periods. A similar pattern was observed for the Soudano-Sahelian and Sahelian zone, with a rainy season offset advancing from 1 September to 10 August and from 20 August to 10 August, respectively, when comparing the 1973-2002 and 2003-2012 periods.

Table 6. Changes to average onset and offset of the rainy season along the different agroclimatic zones (Soudanian, Soudano-Sahelian, and Sahelian) for the period 1973-2012.

\begin{tabular}{|c|c|c|c|c|c|c|c|c|c|}
\hline \multirow[b]{3}{*}{ Period } & \multicolumn{9}{|c|}{ Start of The Rainy Season } \\
\hline & \multicolumn{3}{|c|}{ April } & \multicolumn{3}{|c|}{ May } & \multicolumn{3}{|c|}{ June } \\
\hline & 1st & 10th & 20th & 1st & 10th & 20th & 1st & 10th & 20th \\
\hline \\
\hline \multicolumn{10}{|l|}{ 1983-1992 } \\
\hline \multicolumn{10}{|l|}{ 1993-2002 } \\
\hline \multicolumn{10}{|l|}{ 2003-2012 } \\
\hline & \multicolumn{9}{|c|}{ End of the rainy season } \\
\hline & \multicolumn{3}{|c|}{ August } & \multicolumn{3}{|c|}{ September } & \multicolumn{3}{|c|}{ October } \\
\hline Period & 1st & 10th & 20th & 1st & 10th & 20th & 1st & 10th & 20th \\
\hline 1973-1982 & & & & & & & & & \\
\hline 1983-1992 & & & & & & & & & \\
\hline 1993-2002 & & & & & & & & & \\
\hline 2003-2012 & & & & & & & & & \\
\hline
\end{tabular}




\subsection{Farmers' Awareness of Extreme Weather Events}

On average, most of the farmers surveyed perceived a temperature increase in the last 10-20 years $(p<0.05,92 \%)$, with a higher number of positive responses towards Sahel (95\%) (Table 7). A similar pattern was reported for dry-spell duration, with almost $92 \%(p<0.05)$ of the farmers across the country perceiving longer dry spells during the rainy season. In contrast, the perceptions on precipitation intensity differed between agroclimatic zones. While Soudanian farmers perceived a decrease in precipitation intensity $(60 \%)$, Soudano-Sahelian and Sahelian farmers were aware of increasing precipitation intensity ( $60 \%$ on average) over the last $10-20$ years. Even though most of the farmers perceived an increase in rainfall variability, there were some discrepancies among Sahelian and Soudano-Sahelian farmers (with almost half of the farmers perceiving both an increase and a decrease) when compared to those living in the Soudanian zone ( $71 \%$ perceived an increase). In addition, there were significant differences $(p<0.05)$ between farmers observing a delayed and premature onset and offset of the rainy season (68\% and $85 \%$, respectively) with those acknowledging the opposite. Finally, farmers perceived similar changes in harmattan winds and dust storms along the different agroclimatic regions. Almost two-thirds (65\%) of the farmers perceived an increase in the previous $(p<0.05)$, while the rest asserted a decrease or no changes both in frequency and intensity.

Table 7. Farmers' awareness of changes on weather-related hazards in the different agroclimatic zones (Soudanian, Soudano-Sahelian, and Sahelian).

\begin{tabular}{|c|c|c|c|c|c|c|c|c|}
\hline $\begin{array}{l}\text { AgroclimAtic } \\
\text { Zone }\end{array}$ & $\begin{array}{l}\text { Temp. } \\
\text { Change }\end{array}$ & $\begin{array}{l}\text { Dry Spells } \\
\text { Duration }\end{array}$ & $\begin{array}{c}\text { Precip. } \\
\text { Intensity }\end{array}$ & $\begin{array}{l}\text { Rainfall } \\
\text { Variability }\end{array}$ & $\begin{array}{c}\text { Start Rainy } \\
\text { Season }\end{array}$ & $\begin{array}{c}\text { End Rainy } \\
\text { Season }\end{array}$ & $\begin{array}{l}\text { Harmattan } \\
\text { Winds }\end{array}$ & $\begin{array}{c}\text { Dust } \\
\text { Storms }\end{array}$ \\
\hline \multicolumn{9}{|l|}{ Soudanian } \\
\hline$(-)$ & 5.5 & 5.4 & 60.4 & 16.1 & 28.3 & 94.5 & 29.1 & 29.1 \\
\hline$(=)$ & 5.5 & 9.1 & 1.9 & 12.5 & 5.7 & 0.0 & 9.1 & 9.1 \\
\hline \multicolumn{9}{|c|}{ Soudano-Sahelian } \\
\hline$(=)$ & 3.8 & 1.8 & 5.5 & 3.7 & 10.0 & 28.8 & 18.9 & 24.1 \\
\hline \multicolumn{9}{|l|}{ Sahelian } \\
\hline$(+)$ & 94.6 & 94.3 & 58.3 & 51.4 & 78.4 & 2.6 & 75.7 & 78.4 \\
\hline$(-)$ & 0.0 & 0.0 & 33.3 & 45.7 & 16.2 & 92.1 & 2.7 & 0.0 \\
\hline$(=)$ & 5.4 & 5.7 & 8.3 & 2.9 & 5.4 & 5.3 & 21.6 & 21.6 \\
\hline
\end{tabular}

Legend: means that did not share a letter $(a, b)$ were significantly different $(p<0.05)$ using the Tukey HSD test. Legend: $(+),(-)$ and $(=)$ refers to an increase/decrease/no change in temperature, dry-spell duration, precipitation intensity, rainfall variability; as well as delayed/advanced/no change on the start/end of the rainy season, just like stronger/weaker/no change on harmattan winds and dust storms.

\subsection{Adaptive Capacity and Climate Services}

Almost all farmers affirmed adopting agroecological practices to absorb climate impacts and risks across the country (Figures 5 and 6). The role of indigenous and traditional knowledge on ecosystem-based adaptation was reflected in farmers' responses. The most frequently applied strategies across the country included the application of organic matter $(91 \%)$, followed by minimum tillage $(75 \%)$, crop rotation (62\%), agroforestry, and the use of furrows (both with $58 \%$ ). Such strategies had in common the conservation of soil carbon, reduction of losses from direct evaporation, and preservation of soil nutrients. However, the number of farmers embracing environment conservation strategies differed between regions. For example, Sahelian smallholder farmers widely used, when compared to the Soudanian zone, traditional farming systems to adapt to climate shocks and reduce agrochemical impacts over the environment. This was estimated based on the number of respondents in the Sahel applying organic matter (92\%), zero or minimum tilling (89\%), adopting agroforestry systems $(66 \%)$, associating crops $(63 \%)$, or using zaï pit systems $(29 \%)$. 


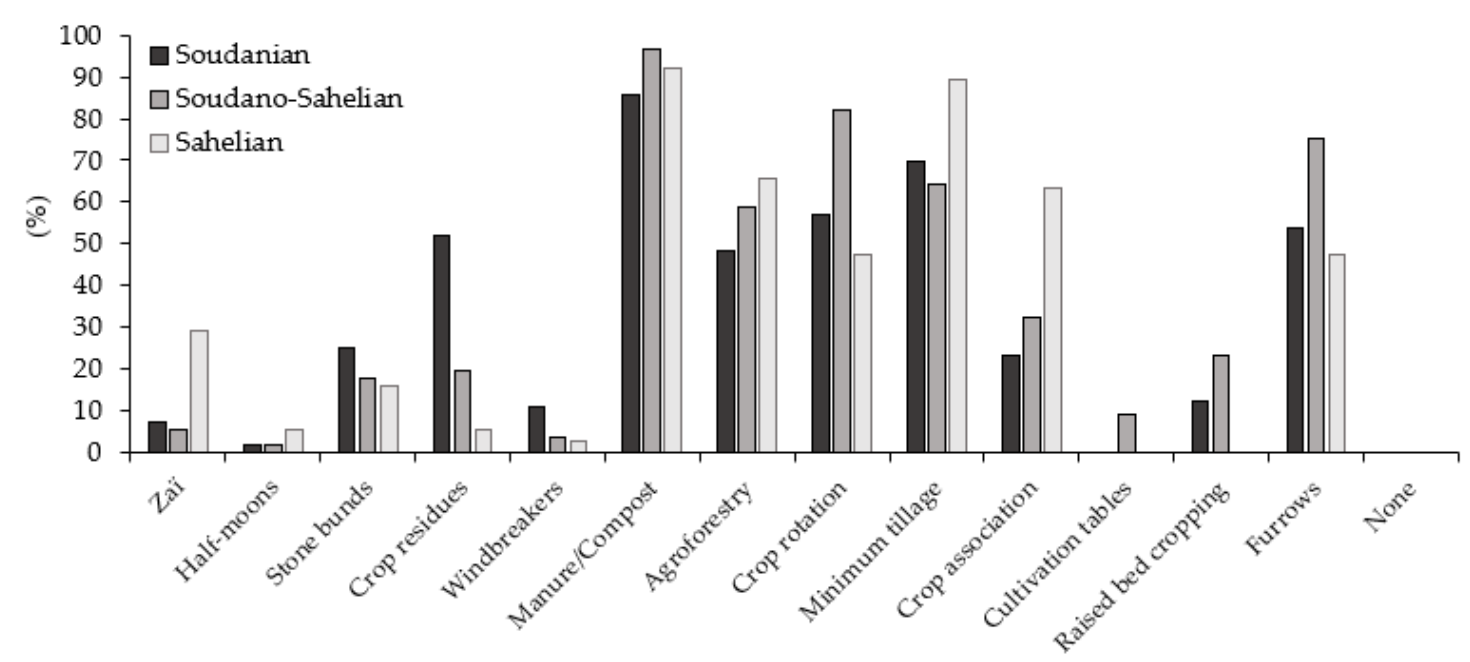

Figure 5. Soil and land management strategies in the different agroclimatic zones (Soudanian, Soudano-Sahelian, Sahelian).

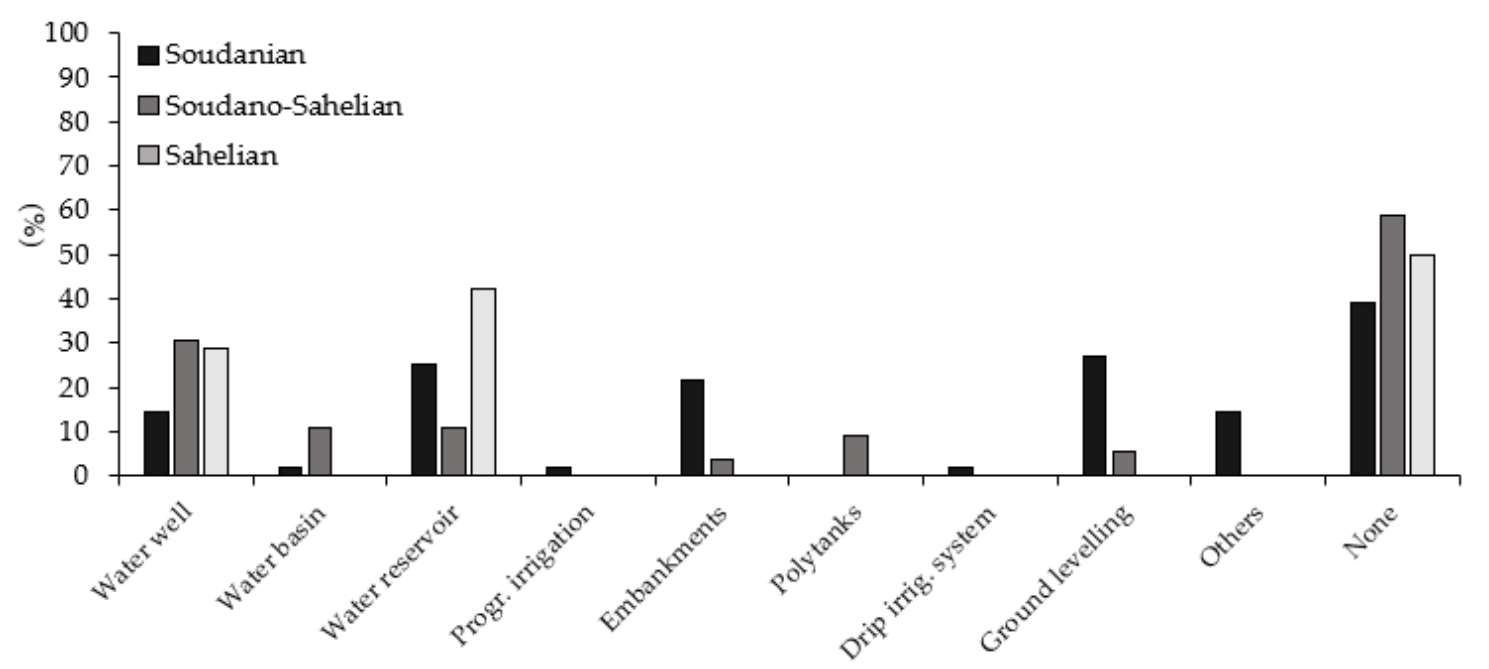

Figure 6. Water management techniques in the different agroclimatic zones (Soudanian, Soudano-Sahelian, Sahelian).

Furthermore, the use of water conservation strategies, including infrastructures for storing water, was relatively low due to the low purchasing power of farmers across the country, particularly of smallholder farmers in the Sahel (Figure 6). In fact, $49 \%$ of the farmers across the country acknowledged having no means to procure water conservation and/or irrigation infrastructures in their fields. The most prevalent strategy noted was shared water resources from reservoirs and water wells ( $26 \%$ and $24 \%$, respectively). The use of technological solutions, such as ground levelling and embankments, were generally embraced by large-scale rice and maize farmers located in the Soudanian zone ( $27 \%$ and $21 \%$, respectively). In addition, the use and type of plant growth regulators (e.g., herbicides) and growth promoters (e.g., fertilizers) were adopted differently across the country (Figure 7). Soudanian farmers widely used agrochemical herbicides ( $93 \%$, e.g., Gliphader), synthetic fertilizers $\left(82 \%\right.$, e.g., urea- $\mathrm{CO}\left(\mathrm{NH}_{2}\right), \mathrm{N}, \mathrm{P}, \mathrm{K}$, and phosphate- $\left.\mathrm{PO}_{4}{ }^{3-}\right)$, as well as pesticides and insecticides ( $41 \%$ and $73 \%$, respectively, e.g., Cypercal and Caiman Rouge); whereas Soudanian and Sahelian farmers, particularly the latter, used the previous products to a lesser extent ( $58 \%$ insecticides, $55 \%$ synthetic fertilizers, $39 \%$ herbicides, and $9 \%$ pesticides, on average). In addition, animal draught tillage was mainly afforded by large-scale farmers in the Soudanian and Soudano-Sahelian zones ( $74 \%$ on average), but fewer in the Sahel $(53 \%)$. A similar pattern was observed for the use of performant 
seeds (e.g., drought tolerant maize genotypes), with $45 \%$ of the farmers having access to seeds in the Soudanian and Soudano-Sahelian zone, but very few in the Sahel (8\%).

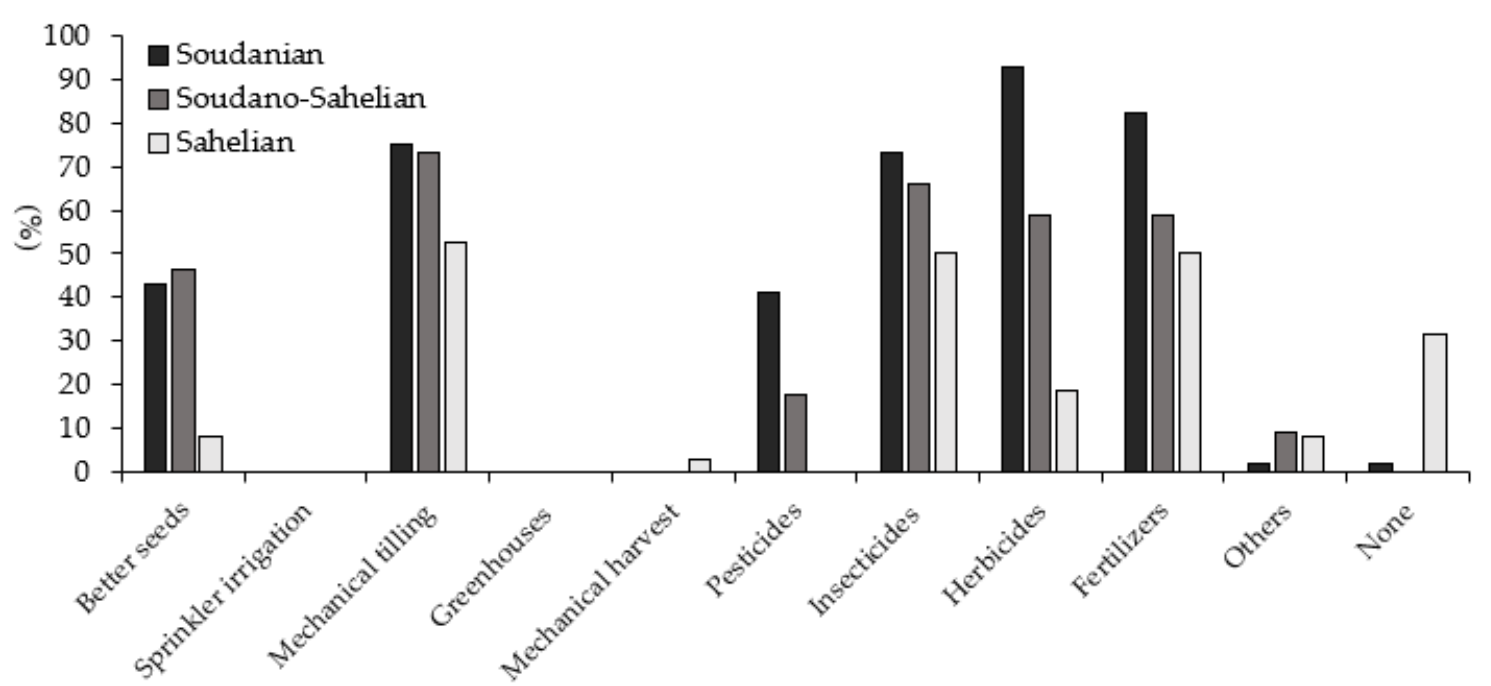

Figure 7. Use of plant growth regulators and agriculture mechanization methods in the different agroclimatic zones (Soudanian, Soudano-Sahelian, Sahelian).

The number of available climate services in Burkina Faso was low, probably because of the lack of generation, provision, and contextualization of information derived from climate databases, research, and modelling. The most effective communication means for delivering climate and weather information to farmers were the radio (39\%), followed by television (TV) $(27 \%)$, word of mouth $(26 \%)$, and mobile phone (SMS) (3\%). While the radio and word of mouth were the main communication means for delivering climate information in the Sahel ( $43 \%$ and $29 \%$, respectively), in the Soudano-Sahelian and Soudanian, farmers accessed climate information through the radio and TV $(38 \%$ and $29 \%$ on average, respectively). Finally, enhanced climate services (e.g., weather alerts on mobile phone-SMS) mainstreamed by the National Meteorological Agency (ANAM) were slowly being introduced but remain far from being distributed at a national scale.

\subsection{Climate Change Impacts and Vulnerability}

As reported in Sections 3.1-3.3, farmers' perceptions on natural hazards had a significant relationship to observed climate change. The evaluation of farmers' perceptions and adoption of soil and water conservation strategies was necessary to better understand the farmers' capability to cope with, respond to, and recover from climate change negative impacts. The combination of low adaptive capacity and lack of institutional support to cope with the adverse impacts of climate change leaves climate sensitive sectors vulnerable to the losses from extreme weather events. Overall, a third (34\%) of the farmers surveyed had migrated in the last 10 to 20 years, with numbers as high as $50 \%$ in the Soudano-Sahelian zone. Among those having migrated, a small number of farmers (22\%) had to flee their homes due to climate-related stressors (drought, flooding, heat-stress, land degradation etc.). However, a large number of respondents $(56 \%)$ did not give a reason behind migration and were displaced because of the lack of job opportunities, which could be indirectly driven by climate change and land degradation. Finally, $10 \%$ of the farmers had to flee their homes due to marriage or conflict in the nearby Ivory Coast.

Greater concern or perceived vulnerability was acknowledged among farmers living in the Sahelian zone, with a decreasing number towards the southernmost parts of the country. On a scale from 0 to 4 (none, low, moderate, high, and very high), almost all farmers ( $>90 \%)$ in all agroclimatic zones perceived their agricultural activities at a moderate to very high vulnerability to climate change and weather-related hazards. For example, Sahelian farmers considered themselves at a very 
high vulnerability to climate change impacts (92\%), while a decreasing number affirmed this in the Soudano-Sahelian and Soudanian agroclimatic zones (73\% and 33\%, respectively).

\section{Discussion}

Survey results on selected farmers' perceptions on past climatic trends reflect climate observations from ground-based weather data from Dori, Ouagadougou, and Bobo Dioulasso (Table 8). Temperature increase was accepted by the majority (92\%) of farmers in all agroclimatic zones, and climate records showed a consistent increase over time both for Tmax $\left(0.04-0.2{ }^{\circ} \mathrm{C}\right.$ decade $\left.\mathrm{e}^{-1}\right)$ and Tmin (0.17-0.41 ${ }^{\circ} \mathrm{C}$ decade $\left.^{-1}\right)$ over the period 1973-2017. The magnitude temperature of increase differed across the country, with the largest changes in the Soudanian and Soudano-Sahelian zones where temperature increase was slightly above values reported in the literature: $0.5-0.8^{\circ} \mathrm{C}$ for the period 1979-2010 for the Sahel region and Western Africa [1-3,5]. Heatwave conditions were reflected in all agroclimatic zones, with a particular increase over the Soudanian and Soudano-Sahelian zone (T40max of six and 60 days year ${ }^{-1}$ between 2013 and 2017, respectively), with persistent extreme warm conditions over the Sahel (T40max around 100 days year $^{-1}$ ). The current T40max (2013-2017) matched the National Centers for Environmental Prediction (NCEP) reanalysis trends for Western Sahel (1989-2009), observing the largest increase in heatwave duration (from 80 to 120 days year ${ }^{-1}$ with Tmax $>41^{\circ} \mathrm{C}$ ) at latitudes ranging between $12-18^{\circ} \mathrm{N}$ [40]. Although heat-stress conditions were not examined independently, farmer surveys showed a consensus on increasing temperatures across the country.

Table 8. Summary of similarities (S) and differences (D) between farmers' perceptions and climate observations along the different agroclimatic zones.

\begin{tabular}{cccc}
\hline Climatic Indicator & Soudanian & Soudano-Sahelian & Sahel \\
\hline Temperature increase & $\mathrm{S}$ & $\mathrm{S}$ & $\mathrm{S}$ \\
Dry spell duration & $\mathrm{S}$ & $\mathrm{S}$ & $\mathrm{S}$ \\
Precipitation intensity & $\mathrm{S}$ & $\mathrm{S}$ & $\mathrm{S}$ \\
Rainfall variability & $\mathrm{S}$ & $\mathrm{D}$ & $\mathrm{S}$ \\
Start rainy season & $\mathrm{S}$ & $\mathrm{S}$ & $\mathrm{S}$ \\
End rainy season & $\mathrm{S}$ & $\mathrm{S}$ & $\mathrm{S}$ \\
Harmattan winds & - & - & - \\
Dust storms & - & - & - \\
\hline
\end{tabular}

Regarding long-term changes in precipitation patterns, increasing inter-annual rainfall variability was perceived by farmers in the Soudanian and Sahelian zone, while statistical indicators (coefficient of variation) corroborated the previous, with a doubling of $\mathrm{cv}$ in Bobo Dioulasso and Dori when comparing the 1973-1982 and 2003-2012 periods. These values were in line with studies providing longer datasets (1950-2013), showing a precipitation reduction (25\%) and higher variability in southernmost parts of the country [5]. In addition, the 20th century reanalysis exhibited a clear multidecadal rainfall variability within the Sahel region [41]; while increasing interannual rainfall variability was reported since the 1960s, due to changes in rainfall patterns and decreases in total annual rainfall [7]. Our study showed a strong decline in annual rainfall between 1973-1982 and 2003-2012 periods in central and northernmost parts of the country, but with a rainfall recovery since 2006. Similar studies conclude that a rainfall recovery in northern parts of the country (Dori and Ouahigouya) has occurred over the past two decades [5]. Therefore, the recent rainfall recovery could be the reason behind discrepancies among farmers across the different agroclimatic zones in terms of rainfall variability and precipitation intensity.

In regard to the characteristics of the rainy season, the present findings from surveys and climatic records were in line with studies reporting a shortening of the rainy season in West Africa and its adverse implications for rainfed agriculture [42-45]. For instance, Diaconescu et al. [45] have observed an onset retreat over the $12-20^{\circ} \mathrm{N}$ latitude and $15^{\circ} \mathrm{W}-15^{\circ} \mathrm{E}$ longitude bands. Some authors suggest that rainfall anomalies during the rainy season were negative (delayed onset) and positive (delayed offset), 
indicating a shift and or displacement of the rainy season [43]. However, the previous findings were discrepant with our study, where most of the farmers (85\%) across the country acknowledged an earlier offset of the rainy season. Trends in climate data presented in this study corroborates farmers' appraisals, displaying a shortening of the rainy season by at least one month in all parts of the country. Regarding heavy precipitation events, approximately two thirds of the farmers in central and northern parts of Burkina Faso reported an intensification of rainfall events. The previous was verified by long-term climatic observations and was reflected during the rainy season of 2009, with downpours exceeding $250 \mathrm{~mm}$ in $24 \mathrm{~h}$ [46]. In this line, Bichet \& Diehiou [13] acknowledged that precipitation had intensified over the 1981-2014 period, with rainfall events exceeding $240 \mathrm{~mm} \mathrm{day}^{-1}$ within the region.

Furthermore, the lack of generation of weather information and scarce means for providing agrometeorological services in Burkina Faso further diminishes the adaptive capacity of farmers to climate change. In order to effectively implement targeted adaptation measures, tailored agrometeorological services that support the whole set of farmers' tactical and strategic decisions becomes fundamental. Providing farmers with advice on seasonal forecasts (e.g., date for land preparation to reduce weeding), crop calendars (e.g., crop variety choice and crop cycle fitted to seasonal forecasts), rainfall monitoring using rain gauges and relation to seasonal forecasts (to avoid sowing failure and re-sowing) can bolster farmers' ability to prepare for and respond to future climate change [47]. The results of the present study provide insight into observed and perceived impacts of climate change, both important for informing climate services and adaptation measures at all levels. Major findings that should be considered in the future development of climate services and adaptation frameworks in Burkina Faso include the identified drivers of cropping systems and adaptation measures, which are primarily market based for Soudanian farmers while Sahelian farmers based their farming systems on low water requirements and subsistence agriculture. The provision of climate services in the country can incorporate these insights into further targeting services most relevant to each region. In addition, adaptation measures should be tailored to the observed and perceived climate context as well as available means of farmers to access necessary resources to implement adaptation measures. Overall, the information presented in our study provides a stronger baseline from which policymakers can inform subnational adaptation planning and providers of climate services can further tailor their products in the future.

In addition, survey results from this study highlight that radio and TV were the main means through which farmers currently receive weather information. As a result, scaling-up of agrometeorological services through the radio and TV will likely be the most effective method for building climate resilience. However, given the increasing access to phones and sustainable improvement in the network throughout the country, other digital services (SMS and phone applications) for mainstreaming agrometeorological information to farmers should be further explored. In fact, the use of these Information and Communication Technologies (ICTs) has been shown to close the gaps between climate information producers and end users, in addition to being effective for building climate resilience among African farmers [48-50].

Future work should consider existing knowledge of communication networks and identified needs of farmers in order to propose measures for strengthening information flows to farm communities. The provision of services and advisories to farmers and end users is multifaceted and requires constant feedback. The present study highlights the need to develop tailored climate services by agroclimatic region and farming systems, as well as to consider the means by which farmers receive information.

\section{Conclusions}

As a result of increasing rainfall variability, shifts in rainy season onset/offset, increased dry-spell duration, intensified precipitation events, and increased heatwave duration, farmers across Burkina Faso have traditionally adjusted their agricultural activities to absorb climatic shocks. For that reason, the most widespread practices are related to soil and water conservation practices that can reduce soil erosion besides enhancing water infiltration rates. However, given the rate of change and 
intensification of natural hazards, these practices seem to be insufficient in the long term. For that reason, decision makers have to develop a roadmap for improving agrometeorological services in Burkina Faso. This includes the identification of challenges, goals, and benefits of providing end users with agrometeorological information for tactical farming decision-making. The national framework on climate services needs to consider the provision of tailored services to end-user needs. Hence, these agrometeorological services have to be tailored to each agroclimatic region and type of agricultural activity (crop or livestock). The provision of climate information needs to be mainstreamed by the Meteorological Agency (ANAM) and canalized, together with extension services, through existing and densely coverage communication means (radio, TV, and mobile phone). Climate services have to include feedback mechanisms where end users can contribute to its strengthening. The engagement of end users along the climate services value chain and, to some extent, on the decision-making process will assure its viability, besides scaling-up the number of potential beneficiaries. The present study provides a steppingstone for building a climate services roadmap in Burkina Faso, with a focus on the perceptions and needs of end-users. The results of the present study can inform future stages of the development of effective climate services and farm advisories in Burkina Faso.

Author Contributions: J.A.-B. (conceptualization, data curation, methodology, investigation, writing, reviewing, and editing), A.D. (supervision), A.D.M. (conceptualization, supervision, and reviewing), A.H. (writing and reviewing), J.S. (supervision), S.O. (supervision and funding). All authors have read and agreed to the published version of the manuscript.

Funding: This research received no external funding.

Acknowledgments: The present study would like to recognize the support of the Institut de l'Environnement et Recherches Agricoles (INERA) for simplifying operational activities in Burkina Faso. Special recognitions to the local master students on agronomy, Guira Amidou, Abdou Gnanda, Louis Nebie and Coulibaly Saturnin from the Université Nazi Boni for their categorical support during this study. Profound thanks to farmers along Burkina Faso for making this research possible.

Conflicts of Interest: The authors declare no conflicts of interest.

\section{References}

1. New, M.; Hewitson, B.; Stephenson, D.B.; Tsiga, A.; Kruger, A.; Manhique, A.; Mbambalala, E. Evidence of Trends in Daily Climate Extremes over Southern and West Africa. J. Geophys. Res. Space Phys. $2006,111$. [CrossRef]

2. Collins, J.M. Temperature Variability over Africa. J. Clim. 2011, 24, 3649-3666. [CrossRef]

3. Mouhamed, L.; Traoré, S.; Alhassane, A.; Sarr, B. Evolution of Some Observed Climate Extremes in the West African Sahel. Weather Clim. Extrem. 2013, 1, 19-25. [CrossRef]

4. Nicholson, S.E.; Nash, D.J.; Chase, B.M.; Grab, S.W.; Shanahan, T.M.; Verschuren, D.; Asrat, A.; Lézine, A.-M.; Umer, M. Temperature Variability over Africa during the Last 2000 Years. Holocene 2013, 23, 1085-1094. [CrossRef]

5. De Longueville, F.; Hountondji, Y.C.; Kindo, I.; Gemenne, F.; Ozer, P. Long-Term Analysis of Rainfall and Temperature Data in Burkina Faso (1950-2013). Int. J. Climatol. 2016, 36, 4393-4405. [CrossRef]

6. Dike, V.N.; Shimizu, M.H.; Diallo, M.; Lin, Z.; Nwofor, O.K.; Chineke, T.C. Modelling Present and Future African Climate Using CMIP5 Scenarios in HadGEM2-ES. Int. J. Clim. 2015, 35, 1784-1799. [CrossRef]

7. Yabi, I.; Afouda, F. Extreme Rainfall Years in Benin (West Africa). Quat. Int. 2012, 262, 39-43. [CrossRef]

8. Hickler, T.; Eklundh, L.; Seaquist, J.W.; Smith, B.; Ardö, J.; Olsson, L.; Sykes, M.T.; Sjöström, M. Precipitation Controls Sahel Greening Trend. Geophys. Res. Lett. 2005, 32. [CrossRef]

9. Olsson, L.; Eklundh, L.; Ardö, J. A Recent Greening of the Sahel-Trends, Patterns and Potential Causes. J. Arid. Environ. 2005, 63, 556-566. [CrossRef]

10. Giannini, A.; Biasutti, M.; Verstraete, M.M. A Climate Model-Based Review of Drought in the Sahel: Desertification, the Re-Greening and Climate Change. Glob. Planet. Chang. 2008, 64, 119-128. [CrossRef]

11. Ouedraogo, I.; Runge, J.; Eisenberg, J.; Barron, J.; Sawadogo-Kaboré, S. The Re-Greening of the Sahel: Natural Cyclicity or Human-Induced Change? Land 2014, 3, 1075-1090. [CrossRef] 
12. Salack, S.; Giannini, A.; Diakhaté, M.; Gaye, A.T.; Muller, B. Oceanic Influence on the Sub-Seasonal to Interannual Timing and Frequency of Extreme Dry Spells over the West African Sahel. Clim. Dyn. 2013, 42, 189-201. [CrossRef]

13. Bichet, A.; Diedhiou, A. West African Sahel has Become Wetter during the Last 30 Years, but Dry Spells are Shorter and More Frequent. Clim. Res. 2018, 75, 155-162. [CrossRef]

14. IPCC. Climate Change 2013: The Physical Science Basis. In Contribution of Working Group I to the Fifth Assessment Report of the Intergovernmental Panel on Climate Change; Stocker, T.F., Qin, D., Plattner, G.-K., Tignor, M., Allen, S.K., Boschung, J., Nauels, A., Xia, Y., Bex, V., Midgley, P.M., Eds.; Cambridge University Press: Cambridge, UK; New York, NY, USA, 2013; p. 1535.

15. Sylla, M.B.; Nikiema, P.M.; Gibba, P.; Kebe, I.; Klutse, N.A.B. Climate Change over West Africa: Recent Trends and Future Projections. In Adaptation to Climate Change and Variability in Rural West Africa; Springer: Berlin/Heidelberg, Germany, 2016; pp. 25-40.

16. Boko, M.; Niang, I.; Nyong, A.; Vogel, A.; Githeko, A.; Medany, M.; Osman-Elasha, B.; Tabo, R.; Yanda, P. Africa Climate Change 2007: Impacts, Adaptation and Vulnerability. Contribution of Working Group II to the Fourth Assessment Report of the Intergovernmental Panel on Climate Change; Parry, M.L., Canziani, O.F., Palutikof, J.P., Van der Linden, P.J., Hanson, C.E., Eds.; Cambridge University Press: Cambridge, UK; New York, NY, USA, 2007; pp. 433-467.

17. Diffenbaugh, N.S.; Giorgi, F. Climate Change Hotspots in the CMIP5 Global Climate Model Ensemble. Clim. Chang. 2012, 114, 813-822. [CrossRef] [PubMed]

18. Niang, I.; Ruppel, O.C.; Abdrabo, M.A.; Essel, A.; Lennard, C.; Padgham, J.; Urquhart, P. Contribution of Working Group II to the Fifth Assessment Report of the Intergovernmental Panel on Climate Change. In Climate Change 2014: Impacts, Adaptation, and Vulnerability. Part B: Regional Aspects; Barros, V.R., Field, C.B., Dokken, D.J., Mastrandrea, M.D., Mach, K.J., Bilir, T.E., Chatterjee, M., Ebi, K.L., Estrada, Y.O., Genova, R.C., Eds.; Cambridge University Press: Cambridge, UK; New York, NY, USA, 2014; pp. $1199-1265$.

19. Ayantunde, A.A.; De Leeuw, J.; Turner, M.D.; Said, M. Challenges of Assessing the Sustainability of (Agro)-Pastoral Systems. Livest. Sci. 2011, 139, 30-43. [CrossRef]

20. Alvar-Beltrán, J.; Dao, A.; Dalla Marta, A.; Saturnin, C.; Casini, P.; Sanou, J.; Orlandini, S. Effect of Drought, Nitrogen Fertilization, Temperature and Photoperiodicity on Quinoa Plant Growth and Development in the Sahel. Agronomy 2019, 9, 607.

21. Mekdaschi, R.; Liniger, H. Water Harvesting: Guidelines to Good Practice; Centre for Development and Environment: Bern, Switzerland, 2013.

22. Younan, M.; Simpson, B.M. Agricultural Adaptation to Climate Change in the Sahel: Expected Impacts on Pests and Diseases Afflicting Livestock; USAID: Washington, DC, USA, 2014.

23. Barbier, B.; Yacouba, H.; Karambiri, H.; Zoromé, M.; Somé, B. Human Vulnerability to Climate Variability in the Sahel: Farmers' Adaptation Strategies in Northern Burkina Faso. Environ. Manag. 2009, 4, $790-803$. [CrossRef]

24. Bado, B.V.; Savadogo, P.; Manzo, M.L.S. Restoration of Degraded Lands in West Africa Sahel: Review of Experiences in Burkina Faso and Niger. 2016. Available online: http://oar.icrisat.org/10754/ (accessed on 31 July 2020).

25. Dörlochter-Sulser, S.; Nill, D. Good Practices in Soil and Water Conservation: A Contribution to Adaptation and Farmers' Resilience Towards Climate Change in the Sahel; GIZ: Bonn, Germany, 2012.

26. Liniger, H.P.; Studer, R.M.; Hauert, C.; Gurtner, M. Sustainable Land Management in Practice: Guidelines and Best Practices for Sub-Saharan Africa; FAO: Rome, Italy, 2011.

27. Nyong, A.; Adesina, F.; Elasha, B.O. The Value of Indigenous Knowledge in Climate Change Mitigation and Adaptation Strategies in the African Sahel. Mitig. Adapt. Strat. Glob. Chang. 2007, 12, 787-797. [CrossRef]

28. Adesina, A.A.; Baidu-Forson, J. Farmers' Perceptions and Adoption of New Agricultural Technology: Evidence from Analysis in Burkina Faso and Guinea, West Africa. Agric. Econ. 1995, 13, 1-9. [CrossRef]

29. Roncoli, C.; Ingram, K.; Kirshen, P. The Costs and Risks of Coping with Drought: Livelihood Impacts and Farmers' Responses in Burkina Faso. Clim. Res. 2001, 19, 119-132. [CrossRef]

30. Maddison, D. The Perception of and Adaptation to Climate Change in Africa; World Bank 699 Policy Research Working Paper; The World Bank: Washington, DC, USA, 2007; Volume 4308, pp. 1-52.

31. West, C.T.; Roncoli, C.; Ouattara, F. Local Perceptions and Regional Climate Trends on the Central Plateau of Burkina Faso. Land Degrad. Dev. 2008, 19, 289-304. [CrossRef] 
32. Mertz, O.; Mbow, C.; Reenberg, A.; Diouf, A. Farmers' Perceptions of Climate Change and Agricultural Adaptation Strategies in Rural Sahel. Environ. Manag. 2009, 43, 804-816. [CrossRef] [PubMed]

33. Ouédraogo, M.; Dembélé, Y.; Somé, L. Perceptions et stratégies d'adaptation aux changements des précipitations: Cas des paysans du Burkina Faso. Sécheresse 2010, 21, 87-96. [CrossRef]

34. Zorom, M.; Barbier, B.; Mertz, O.; Servat, E. Diversification and Adaptation Strategies to Climate Variability: A Farm Typology for the Sahel. Agric. Syst. 2013, 116, 7-15. [CrossRef]

35. Fonta, W.M.; Sanfo, S.; Ibrahim, B.; Barry, B. Farmers Awareness, Perception of Climate Hazards and their Willingness to Participate in Crop Insurance Schemes in Southwestern Burkina Faso. Procedia Environ. Sci. 2015, 29, 7-8. [CrossRef]

36. Sanfo, S.; Barbier, B.; Dabiré, I.W.; Vlek, P.L.; Fonta, W.M.; Ibrahim, B.; Barry, B. Rainfall Variability Adaptation Strategies: An Ex-Ante Assessment of Supplemental Irrigation from Farm Ponds in Southern Burkina Faso. Agric. Syst. 2017, 152, 80-89. [CrossRef]

37. National Oceanic and Atmospheric Administration (NOAA). National Centres for Environmental Information. Available online: https://www.ncdc.noaa.gov/data-access. (accessed on 15 May 2018).

38. Beguería, S.; Tomas-Burguera, M.; Serrano-Notivoli, R.; Peña-Angulo, D.; Vicente-Serrano, S.M.; González-Hidalgo, J.C. Gap Filling of Monthly Temperature Data and its Effect on Climatic Variability and Trends. J. Clim. 2019, 32, 7797-7821. [CrossRef]

39. Ibrahim, B.; Polcher, J.; Karambiri, H.; Rockel, B. Characterization of the Rainy Season in Burkina Faso and it's Representation by Regional Climate Models. Clim. Dyn. 2012, 39, 1287-1302. [CrossRef]

40. Vizy, E.K.; Cook, K.H. Mid-Twenty-First-Century Changes in Extreme Events over Northern and Tropical Africa. J. Clim. 2012, 25, 5748-5767. [CrossRef]

41. Berntell, E.; Zhang, Q.; Chafik, L.; Körnich, H. Representation of Multidecadal Sahel Rainfall Variability in 20th Century Reanalyses. Sci. Rep. 2018, 8, 1-8. [CrossRef]

42. Kunstmann, H.; Jung, G. Impact of Regional Climate Change on Water Availability in the Volta Basin of West Africa. IAHS Publ. 2005, 295, 75-85.

43. Biasutti, M.; Sobel, A.H. Delayed Sahel Rainfall and Global Seasonal Cycle in a Warmer Climate. Geophys. Res. Lett. 2009, 36. [CrossRef]

44. Van de Giesen, N.; Liebe, J.; Jung, G. Adapting to climate change in the Volta Basin, West Africa. Curr. Sci. 2010, 98, 1033-1037.

45. Diaconescu, E.P.; Gachon, P.; Scinocca, J.; Laprise, R. Evaluation of Daily Precipitation Statistics and Monsoon Onset/Retreat over Western Sahel in Multiple Data Sets. Clim. Dyn. 2015, 45, 1325-1354. [CrossRef]

46. Taylor, C.M.; Belušić, D.; Guichard, F.; Parker, D.J.; Vischel, T.; Bock, O.; Panthou, G. Frequency of extreme Sahelian storms tripled since 1982 in satellite observations. Nature 2017, 544, 475. [CrossRef] [PubMed]

47. Tarchiani, V.; Camacho, J.; Coulibaly, H.; Rossi, F.; Stefanski, R. Agrometeorological Services for Smallholder Farmers in West Africa. Adv. Sci. Res. 2018, 15, 15-20. [CrossRef]

48. Roudier, P.; Muller, B.; D'Aquino, P.; Roncoli, C.; Soumaré, M.; Batté, L.; Sultan, B. The Role of Climate Forecasts in Smallholder Agriculture: Lessons from Participatory Research in Two Communities in Senegal. Clim. Risk Manag. 2014, 2, 42-55. [CrossRef]

49. Ouédraogo, I.; Diouf, N.S.; Ouédraogo, M.; Ndiaye, O.; Zougmoré, R.B. Closing the gap between climate information producers and users: Assessment of needs and uptake in Senegal. Climate 2018, 6, 13. [CrossRef]

50. Silvestri, S.; Richard, M.; Edward, B.; Dharmesh, G.; Dannie, R. Going digital in agriculture: How radio and SMS can scale-up smallholder participation in legume-based sustainable agricultural intensification practices and technologies in Tanzania. Int. J. Agric. Sustain. 2020,1-12. [CrossRef]

(C) 2020 by the authors. Licensee MDPI, Basel, Switzerland. This article is an open access article distributed under the terms and conditions of the Creative Commons Attribution (CC BY) license (http://creativecommons.org/licenses/by/4.0/). 